DOI: $\underline{10.20472 / E S .2020 .9 .2 .006}$

\title{
FACTORS PROPORTION IN TRADE PATTERN AND INTERNATIONAL CAPITAL FLOWS INTERACTION IN ASEAN+4 COUNTRIES
}

\section{NI PUTU WIWIN SETYARI}

\begin{abstract}
:
The classic thesis by Mundell, with the modification of Heckscher-Ohlin model, stated that a substitution relation flows between trade and international capital. Mundell showed that the equilibrium price of a commodity can be obtained through international factor mobility in the absence of trade in goods or vice versa, if the trade barriers of the factor price equilibrium are eliminated. Therefore, the factor price equalization will be achieved without requiring the exchange of goods between countries. Consequently, the study of international trading and capital flows is more frequently studied separately. However, empirical data have shown the contradictory phenomena in which both of them are interrelated and complementary, but how the two interact is still relatively rarely observed.

Some constructions of new theories indicate that interactions between them can be studied through several channels; one of them is through the change in comparative advantage. This paper tries to analyze the interaction between trade and international capital flows in ASEAN countries +4 (ASEAN plus India, China, Japan, and Korea). The countries included in this group are important players in international trading and represent the world's largest trading integration. The interaction between trade and international capital flows is linked via change of trading structure, as seen from the intensity of the use of production factors in the industry in each country. The results of the study are consistent with the theory that capital will flow to countries that have a capital-intensive industrial structure. This then leads to an increase in the deficit in the country's current account balance.
\end{abstract}

\section{Keywords:}

Trade, comparative advantage, the proportion of international factors, capital flows, panel regression analysis

JEL Classification: E22, F10, F20

\section{Authors:}

NI PUTU WIWIN SETYARI, Faculty of Economics and Business, Udayana University, Indonesia, Email: wiwin.setyari@unud.ac.id

\section{Citation:}

NI PUTU WIWIN SETYARI (2020). FACTORS PROPORTION IN TRADE PATTERN AND INTERNATIONAL CAPITAL FLOWS INTERACTION IN ASEAN+4 COUNTRIES. International Journal of Economic Sciences, Vol. IX(2), pp. 94-110., 10.20472/ES.2020.9.2.006 


\section{Introduction}

Both goods liberalization in the real sector and international capital flows in the financial sector are processes of globalization. However, there have not been a lot of studies about how both interact until recently. In previous studies, both of them were put into two separate areas, so that it is recognized that the interaction of goods trading and international capital flows can jointly determine the allocation of global capital as well as changing trading patterns among countries. The reason why there is still a disregard for the conveyance of production factors in the models of international trade is that its analysis has been using the traditional trade theory. Classical theory seems to consider the immobile factors of international production as the basic reason for the existence of international trade (Springer, 2000).

One of the classical theories which was used as the basic analysis is the Heckscher-Ohlin model in stating the difference in the ownership of resources among countries as drivers of trade. International trade allowance will increase demand for labor-intensive products and also decrease demand for capital-intensive products in countries with overwhelmed labor resources. In contrast, it will make a demand and a real return for capital highly increased in some countries which are comparatively superior at producing capital-intensive goods. Therefore, trade will occur among countries that have different industry characteristics, such as developed countries with abundant capital-intensive products, compared to poor or developing countries that are actually richer in labor (labor-intensive products).

The passing of capital inflows in the Heckscher-Ohlin model framework was first stated by Mundell (1957). This model predicts that trade in substitute commodities will be perfect together with direct movement of production factors if owned resources among the countries are not too different. Mundell (1957) shows that the equilibrium of commodity prices can be obtained through international factor mobility in the absence of trading in goods, or otherwise it can be generated from the sale of goods of immobility capital if the barriers to trade are eliminated.

Several advanced studies have shown that the models formed by modification, with the standard assumption of the $\mathrm{HO}$ model, are more likely to provide complementary results, compared with substitution between goods trade and factor trade (Wong, 1986). There are several ways in which these models give different results with the initial model of Mundell (1957), which include the possibility of inter-country differences in technology, the entering of production tax, a monopoly market structure, external economy scale or distortions in market factors, and allowing foreign capital to support the development of domestic economies. In all cases, the increase in foreign direct investment is able to support the growing of international trade (Goldberg and Klein, 1999).

What is the interaction with the flow of that capital with goods trading will then be a question. Two important phenomena which grow in the global economy are the integration of trade and financial, and the increase of labor or productivity in developing countries. The open economy models predict that capital flows enter through the developing countries, but the reality is not in accordance with the facts (Jin, 2012). The phenomenon that occurs then is the power of that two phenomena have changed the comparative advantages of a country which, in turn, alter the structure of trade and lead to the allocation of capital globally.

The interesting study development in examining the interaction between trading and capital flows with the possibility of transmission of goods and capital is made by Jin (2012). He developed a general equilibrium framework that integrates the paradigm of proportion or intensity factors in products, which trade with the flow of capital that allows them to interact with one another. The result is contradictory with the predictions of standard macroeconomics, i.e. that a permanent increase in the labor force or labor productivity in a country will encourage the 
release of capital. Moreover, capital flows from developing countries to developed countries when those two countries are integrated.

The relations of goods trades with capital as the main focus has been shown in several studies, such as the study from Antràs and Caballero (2009). They indicate that trade in goods and capital flows are complementary, especially in the southern countries; the developing countries have relatively fewer organized financial institutions than the northern countries, which are more advanced in this respect. The process of deeper trade integration will increase the incentive influx of capital to the southern countries. Moreover, the study by Zhang (2012) shows that capital flows were considerably greater after the beginning of trade liberalization, especially in developing countries. The proposition of models and empirical data has shown that trade liberalization does not necessarily lead to global imbalances; moreover, trade liberalization could eliminate the imbalance in economic integration.

The research in this paper tries to analyze the interaction of goods trade, in paradigms of proposition, intensity factor, as well as the capital flows in ASEAN+4. The economy in Southeast Asia had been integrated when the Association of Southeast Asian Nations (ASEAN) was formed. To improve the ability of ASEAN countries to face the global economic slowdown, the ASEAN with FTA partner countries formally signed an agreement to form a Regional Comprehensive Economic Partnership (RCEP). This agreement signifies the intention and commitment of ASEAN to play a leading and central role in the economic regional architecture. RCEP will oversee the largest regional trade arrangements to this day with a GDP combination of $\$ 19.78$ trillion on US-based figures in 2011 (ASEAN Secretariat, 2012).

The results of this study are expected to provide an overview of factors and proportion influence on international trading structure of a country, to the macroeconomic conditions that until recent times have not been much discussed. This study in particular tried to observe the proportion factor influence which forms comparative advantage in the trading of each country to capital flows. The theory predicts capital flows that will be going into the country which tends to have products that are capital-intensive, seen from the deficit of current accounts. This paper is further organized as follows: Chapter II contains the review of literature relating to international trading and international capital flows; Chapter III contains the data and methodology used; Chapter IV contains the discussion; and Chapter V has the conclusions.

\section{Relations of Goods Trade Liberalization and International Capital Flow}

Mundell (1957), by using the analytical framework of the model HO, stated that the displacement of commodity is a substitute for the displacement factor. An analysis of Mundell sees that he describes how the increase in trading impediments stimulates factor movements and trading itself. The absence of obstacles in trading caused the commodity price level to occur, and although the factors are not able to move, there will be a tendency towards an equilibrium price factor, better known as factor price equalization. In contrast, it will also occur when the factors' movement generates a perfect balance of price factors. However, if goods trade does not occur, the balance of commodity still tends to be formed. Substitution between the displacement factor to the goods movement or trade would be perfect with a few assumptions: 1) the production function is homogeneous in the first degree, i.e. the marginal productivity relatively and absolutely depends on the proportional use of certain factors, and is identical in both countries; 2) one commodity needs a proportion of one factor type in a greater amount compared to the other commodities at several levels of factor price in each point of the production function; 3 ) 
owned factors resources lead to specialization. It is explicitly stated that the factor in this case is physical capital; therefore, it does not cause problems in the balance of payments during the transmission between countries.

An analysis by Mundell that used the framework of the $\mathrm{HO}$ model may be explained simply: if there are no obstacles in the trade and capital movement, by the same marginal product in both countries, there will be no transfer of capital because the price factor in both countries is equal. Markusen (1983) tried to question the classic opinion of Mundell about the substitution relationship between free trade with the movement of production factors. Moreover, this was able to show that they are more likely to be complementary than substitutes. Some other assumptions tried to be modified in five different models, namely: 1) identical technology in both countries; 2) identical preferences; 3) constant returns to scale; 4) perfect competition; and 5) absence of domestic obstacles in both countries. The conclusion is that there is a complementary relationship from those five models. It was based on the fact that the factor price which is used intensively to produce export goods would be of relatively high worth. Therefore the factors of production will move to other state industries that also use them intensively in producing goods that will be exported; thus the development of trade will occur. The implication of the condition above is a complementary relationship between trading and the movement of factors.

Schiff (2006) conducted a re-examination of the Markusen analysis by considering some conditions, namely: 1) eliminating all obstacles in the movement of factors when there are various levels of protection; and 2) the change in trade when there is the free factors movement. The conclusion is that the substitution relationship occurs when there is a high level of protection; complementary occurs when the level protection is low; and either a complementary or a substitution will occur when there is an increase or reduction in the degree of protection from low to high, or vice versa.

Changes in the trading structure and specialization patterns can also affect capital flows (Jin, 2012). The examples to illustrate the relationship between the composition of a country's production and demand and supply of capital are the use of specialization perfect case. Let us assume about a state, State A, which fully specializes in production that is capital-intensive and uses capital and labor as inputs. Country $B$ fully specializes in the production of labor-intensive goods which only use labor as an input. State $B$ generates wages, but because of the absence of demand for capital, wages will always be kept in State A. The surge in the number and productivity of labor in Country B will only bring capital outflows leading to State A.

The demand for capital in a country is relative to the existing savings dependent on the structure of the industry. An industrial structure that is leaning towards capital-intensive sectors will face greater investment demand, and because of that there will be an additional output portion for investment. At the same time, it decreases the addition of output portion for wages, contrary to the countries that concentrate on production of a labor-intensive nature. Therefore, in a fully integrated economy world, a country that had been a shock in the labor force or productivity that caused the changes of industry structure which led to the goods that are laborintensive, will tend to net capital outflow (Jin, 2012).

In the perspective of different development of the financial system between countries, Antràs and Caballero (2009) also construct a model that generates propositions of a complementary relationship between international goods trades with capital flows caused by the presence of heterogeneity. ${ }^{1}$ Developing countries, or what they call "the South" have less

\footnotetext{
1 They highlight two dimensions of heterogeneity in financial frictions. First, there is cross-country heterogeneity. The ability to pledge future output to potential financiers is higher in rich "North" than in developing "South." Second, there
} 
developed financial institutions. Therefore, they have more borrowing constraints that more stringent than in constrained sectors. Imperfections in financial terms encouraged the appearance of a comparative advantage which has a similar effect with a comparative advantage in the $\mathrm{HO}$ model of trade liberalization. Trading liberalization increases the demand for goods produced by unconstrained sectors in the South, and encourages them to specialize in the production of such goods. Therefore workers in the South will be allocated to the unconstrained sectors which in turn increase aggregate demand for capital because the sector does not have the borrowing constraint. Therefore, the marginal return on capital in the southern countries will be higher than in the northern countries. Consequently, it will attract the influx of more capital. In particular, the result of their derivation model shows that in this world where countries only differ in a financial system development and economic sectors in terms of financial dependence on financing, trade integration will reduce the gap between the real rate of return of capital in the "North" and "South".

In a different context, Zhang (2012) in his research on the relationship of trading liberalization and capital flows in the perspective of comparative advantage and heterogeneous enterprise showed that there is a pattern of "S" from capital flows in response to trading liberalization. Capital outflows move from developing countries to developed countries. There are two mechanisms which are said to be the driving force of changes in capital flow that accompany trade liberalization. The first is the increase in overall productivity in the two countries, which become one of the important benefits of trade liberalization because of the effects of export options. Higher productivity will produce higher marginal output capital, which in turn increases the rental rate and attracts more capital inflows, with the assumption that the movement of labor between countries is limited.

The second mechanism is the reallocation of labor from capital-intensive sectors to laborintensive sectors. Trading liberalization increases the demand for products that are laborintensive and reduces the demand for capital-intensive products in countries with abundant labor. Instead, capital demand and the capital return are real in a country that has a comparative advantage in the production of goods that are capital-intensive. The consequence is that capital is expected to move from less capital countries to the countries with high capital. Consequently, both mechanisms give a boost to the contradictory responses of capital flows. The empirical study in China showed both mechanisms.

Different conditions put forward by Abrego (1999), using general equilibrium models to quantify the welfare effects of trading liberalization, as well as calculating the optimal tariff structure for Costa Rica among the enforcement of policies that encourage trade and capital flows to tax foreign capital. The conclusion is that, if the country gives tax for foreign capital and the credit system, the lifting of the import tariff was detrimental to Costa Rica. It is caused due to the removal of tariff trigger capital outflows and loss of tax revenue of greater value than the positive effects of free trade. Because of that, import tariff structure for Costa Rica's economy does not have a zero tariff, but rather a mix of import tariffs and subsidies which are positive. Optimal tariff is relatively low which basically reflects the fact that the role of foreign capital in the economy is relatively moderate.

is cross-sectoral heterogeneity. Even when operating under a common financial system, producers in certain sectors find it more problematic to obtain financing than producers in other sectors. 


\section{Data and Methodology}

This paper tries to look at the interaction between trade in goods in the ASEAN+4 with international capital flows. The model which was used in this paper is the modified HeckscherOhlin-Mundell (HOM) model with the characteristic overlapping generations' economy, where everyone lives in two periods, which are to supply the labor in the first period, and retire when they old. Every country is assumed to have preferences and the same production technology. That goods are combined to produce goods that are used for consumption and investment. Preferences and production technologies assumed to have the structure and the same parameter values among countries. However, the technology used is different in two aspects, namely: 1) in each country using only domestic labor; and 2) the provider of goods between countries depending on specific productivity and labor changes.

Solutions for equilibrium conditions in each country were formed based on three existing assumptions, namely: 1 ) the elasticity of goods substitution is unitary $(\theta=1)$;2) consumers have a preference in the form of a logarithmic $(\rho=1)$; and 3 ) adjustment technology of capital in the form of a log-linear. When $\theta=1$, the relative change in the output will be completely replaced by the relative change in the price so that the nominal value of output remains constant across sectors. The second assumption simplifies the problem of consumption or savings and causes private saving in that it does not depend on the real rate of return. Moreover, the third assumption describes the specification of the use capital in the form of goods producing an item $i$, in a country $j$, in period $t$ which is influenced by the investment goods and capital stock of the period. The combination of these three assumptions has implications for the global ratio of aggregate investment-output ratio and the investment-output level of the global industry becomes constant.

Based on these assumptions, the evolution of the capital stock in each sector $i$, in each country $j$, is determined only by the key variable that is the present discounted value of the expected commodity $i$ produced domestically. Part of global investment allocated to industry $i$ is then determined based on the value-weighted share capital, where the higher weighted capital large in industry $i$ is relative to the weighted-average share capital, thus the larger portion of the global investment coming into the industry. The portion of investment country in industry $i$ then becomes the key variable that determines the evolution of the capital stock and the aggregate investment of a country. This means that the larger the state $j$ produce goods $i$, will cause the amount of investment in product $i$ allocated to state $j$. Investment in each country $j$ is not only associated with the production of the expected size, but also the composition of production where the greatest weight is given to the portion of future production of goods that are capital-intensive (composition effect). In contrast with the model of the sector, the relative size of country $j$ can be seen from the portion production which only applied to producing goods globally. The existence of positive shocks in the form of improved technology or labor force permanently abroad, which effectively increase the share of overseas production globally, will reduce the investment in the country (convergence effect).

At each period $t$, the total net foreign assets (NFA) in each country are the value of a claim of foreign assets minus the value of assets held abroad in the country. NFA economic value is equal to the value of labor savings (young population) minus the value of capital stock needed for domestic production in the same period. The current account (CA) of a country in period $t$ by definition is the NFA change between periods $t-1$ and $t$, which can be expressed as follows:

$$
C A_{t}^{h} \equiv N F A_{t}^{h}-N F A_{t-1}^{h}
$$


If a country experiences a boom in labor (productivity), there will be an increase in revenue received by a young population, who are the savers in the economy. Since the rental rate in each country is equal, as a consequence of the same production technology, the savings will be allocated both inside and outside the country, which leads to capital outflows. The liberalization of trade allows a country rich in capital to expand to the sectors that are capitalintensive and export these products as a response to the employment boom in the country which has abundant labor. As a result, the return on capital will increase in sectors that are capital-intensive, and when investment is greater it will encourage higher capital inflows from abroad.

Revealing the value of capital intensity, $k_{t}=K_{t} / L_{t}$, is a reflection of the comparative advantage of the country. The decrease in $k_{t}$ due to high labor productivity or boom employment means the country has a comparative advantage in the larger workforce. Therefore, the country will specialize in products that are labor-intensive, and a shifting production which increases GDP caused by increased salary or wage income will occur. A country whose production structure tends to be capital-intensive has a small labor income in GDP and a low savings rate. On the other hand, the country that has an industry structure which concentrates on the production of labor-intensive products is able to have a portion of a relatively large labor income to GDP; hence the ratio of savings to GDP is a negative function of $k t$. In other words, the greater the savings to GDP ratio, the lower the capital/labor ratio of the country. A cut-off point, where domestic savings (provided by the young population) are sufficient to fill the needs of domestic investment, will bring balance in the capital/labor ratio, so it is not necessary to have foreign assets accumulation. The positive shock of a rise in labor which reduces the capital/labor ratio in period $t$ brings the lead to changes of composition which cause an increase in savings and supply exceeds investment demand.

The direction of capital flows as a consequence of globalization and the shock of labor and productivity is described by Jin (2012) with the following proposition. Suppose there are two countries that originally are the autarky and open in period $t$, hence the current account (ratio to GDP) in period $t$ to the country is:

$$
C A_{t}=\frac{\frac{\beta}{1+\beta}\left(1-k_{t}\right)}{k_{t}\left(\frac{\boldsymbol{S}_{k}}{\boldsymbol{S}_{l}}+\frac{\beta(1-\phi)}{1+\beta}\right)+1}
$$

which $\beta$ shows the discount factor and $0<\beta<1$. $s_{k}$ is the weighted-average capital share, $s_{l}$ is the weighted-average labor share, and a value $\phi_{>} 0$ if all the open country in period $t$, a positive shock due to the increasing number of labor force will decrease the ratio of capital/labor in period $t$, which causes a change in the composition of the bid amount of savings to be higher than the investment needs. This difference will increase the stock of NFA and encourage capital outflows.

$$
N F A_{t}=\frac{\frac{\beta}{(1+\beta)\left(1-k_{t}\right)}}{k_{t}\left(\frac{\boldsymbol{S}_{k}}{\boldsymbol{S}_{l}} \frac{\beta(1-\phi}{1+\beta}\right)+1}
$$

Therefore, the model proposition which developed by Jin (2012) explicitly states that there is an increasing current account deficit in countries specializing in production of a capital-intensive nature when international trade is opened.

This was tested in this paper using thirteen years period, from 2005 to 2017 . Because this study uses a balance panel data, we use a period of time that has complete data for all variables. 
Capital stock issued by the Penn World Table (PWT 9.1) releases the latest data for 2017, so the analysis is limited to 2017. The focus of the test is on Asian countries (ASEAN plus India, China, Korea, and Japan) and integrated in the RCEP. ${ }^{2}$ Data analysis was conducted by a panel of 13 countries. Testing is done by looking at whether countries increasingly specialize in products that are capital-intensive, and whether the current account deficit is also growing as predicted by theory or not. There are two stages to be performed; the first step is to determine the pattern of specialization or reveal the comparative advantage of each country, through revealed capital intensity, while the second stage is to see whether or not the change in the intensity of these factors is related to changes in the current account.

The first stage is to determine the pattern of specialization of each country that is better known as the Revealed Comparative Advantage (RCA), which was first introduced by Balassa (1965). Studies by Romalis $(2004)^{3}$ succeeded in proving the theory that the proportion of owned resources factors of a country is a determinant of the structure of commodities in international trade. Another method to bring up the RCA of the intensity of the use of production factors in a product is the index of Revealed Factor Intensity (RFI) for each product that is traded as a weighted average of resource exporting countries with such variants as the Balassa RCA index scales to ensure that the size of the country does not interfere with the ranking of goods (Shirotori, Tumurchudur, and Cadot, 2010). This index is constructed using a methodology developed by Hausmann, Hwang, and Rodrik (2005), later known as Prody. Prody counting reveals technology content of a product with the weighted average GDP per capita of countries which export products, using RCA indices such products as the scales. The idea is a product that is exported by high-income countries and more likely to be technology-intensive compared to countries that have a low income. Revealed Capital Intensity $(\mathrm{RCl})$ is calculated as follows (Shirotori, Tumurchudur, and Cadot, 2010):

$$
k_{i}=\sum_{j} \omega_{i}^{j} \frac{K^{j}}{L^{j}}
$$

where $K$ is the capital stock in country $j$ and $L^{j}$ is labor force. Weighted weights, ${ }^{\omega_{i}^{j}}$, variant of the Balassa index is calculated by:

$$
\omega_{i}^{j}=\frac{x_{i}^{j} / x^{j}}{\sum_{j}\left(x_{i}^{j} / x^{j}\right)}
$$

where $x_{i}^{j}$ is product export of product $i$ from country $j, x^{j}$ is the total exports of country $j$, and $\sum_{j}\left(x_{i}^{j} / x^{j}\right)$ is the $i$ total products worldwide. In order to eliminate the problem because the value of the RCA index is large (ranging from zero to infinity) resulting from the value of the denominator tends to approach a value of zero (the portion of a product in world trade) at the smallest level of data, thus the tricks have been used to ensure the weight value close to unity.

2 Except Myanmar due to data limitation.

${ }^{3}$ A similar technique was used by Jin (2012) in his empirical testing to find RCA value using factors intensities and products' market share in international trading. 


$$
\sum_{j} \omega_{i}^{j}=\sum_{j} \frac{x_{i}^{j} / x^{j}}{\sum_{j}\left(x_{i}^{j} / x^{j}\right)}=\frac{1}{\sum_{j}\left(x_{i}^{j} / x^{j}\right)} \sum_{j}\left(x_{i}^{j} / x^{j}\right)=1
$$

Revealed capital intensity was calculated as:

$$
R C I_{j t}=\frac{K_{j t}}{L_{j t}}
$$

where $K_{j t}$ is the capital stock value of country $j$ in period $t$ which is obtained from the Penn World Table 9.1, whereas $L_{j t}$ is the labor force of a country $j$ in period $t$ which is taken from the publication of the World Bank. Capital intensity value indicates the amount of capital that is used by a one-person workforce. The greater the capital intensity indicates that the nature of the industry is capital-intensive. Value changes in capital intensity over time in each country will then be used to detect whether there was a relationship between changes in a country's capital intensity with changes in the current account as a way to test the consistency of the theory. The model is formed as follows:

$$
C A_{j t}=\alpha+\beta_{1} R C I_{j t}+\beta_{k} X_{j t}^{k}+u_{j t}
$$

where $C A_{j t}$ the ratio of current account to GDP of country jin period $t$, while $R C l_{j t}$ reflecting revealed capital intensity which reflects the intensity of use of factors of production in country $j$ in period $t . X_{j t}^{k}$ is a collection of other explanatory variables which are generally said to be a determinant of the current account of a country, as used in Chinn and Prasad (2003) and Gruber and Kamin (2005). The variable used here is $G D P_{j t}$ which is GDP growth of country $j$ in period $t$, Trade $_{j t}$ is the ratio of trade (exports plus imports) to GDP, which reflects the openness of the economy of a country, $P O P_{j t}$ is the ratio of the working-age population (aged 15-64 years) to total population as a reflection of the influence of population on the current account. Another

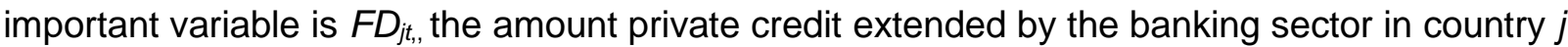
in period $t$. This variable is intended to look at the effect of institutional development financial institutions to the current account as stated by Antràs and Caballero (2009). The main proposition of their theory is that capital will flow to countries with less developed financial institutions because they give a higher interest rate compared to countries with well-established financial institutions.

In order to control the endogeneity problem caused by the uncontrolled release of other variables that correlate with current account and also affects it, a fixed effect method is used, among both countries and time. Endogeneity bias arises when government policies of each country are different in an effort to attract a steady flow of capital to boost investments in the country. The creation of a climate more conducive to the development of better infrastructure is often done. Bias may also possibly emerge from the policies of each country in determining how open they want the economy to be, and how control over international capital flows is determined. Methods to overcome any endogeneity issues are to incorporate the estimation of fixed effects or instrumental variables (Wooldridge, 2005). Because the values of the unobserved variables do not vary over time and among countries, the estimates of the coefficients can provide consistent results. 


\section{Discussion of Results of Analysis}

The economies of ASEAN countries have become part of the East Asian miracle (Park, Park, and Estrada, 2008). Singapore is a new industrial economy along with Hong Kong, Korea, and Taipei. However, Indonesia, Malaysia and Thailand have also been transformed from stagnant agricultural economies to dynamic manufactures economies through continuous growth and industrialization. The ASEAN Economic sector, particularly Vietnam, also has begun to grow at a relatively fast consistency.

The story of the spectacular development of Asia, especially ASEAN, which grew from a backward agricultural country into a global factory in 50 years, is considered an economic miracle. In the 1960s developing countries in Asia experienced a scarcity of natural resources with a high poverty rate; it was even almost impossible to see any economic development. However, ASEAN countries have a supply of cheap labor. They are also geographically close to Japan who have multinational corporations (MNCs) which are efficient and looking for a place to relocate production to cheaper locations in Asia. Multilateral relations through the WTO framework and open regionalism to support APEC strengthen ASEAN international trade policy. Foreign trade policy is based on an outward-oriented development strategy, a high level of domestic savings, the creation of strong infrastructure, and investment in human capital. High demand of the world economy will import goods from Asia that are labor-intensive, and lower tariffs in the markets of developed countries attracted the entry of FDI-related trade, and the flow of foreign aid also marked a growth in Asia.

The composition of capital flows to developing countries has evolved over time. The flow of foreign direct investment (FDI) coming into developing countries increased from $15 \%$ in $1980-84$ to a range of $44-49 \%$ in $2000-04$. However, the FDI which flows into ASEAN member countries is about approximately $25.7 \%$ in the period $2000-06$. This value is smaller than the period 1995-99, which reached an average of 35\% (Aldaba and Yap, 2009).

Economic openness ASEAN countries can be seen from their initiative in forming a free economy, both among members of ASEAN, through ASEAN and FTA partners, and among ASEAN countries with other countries through bilateral agreements. ASEAN economies will be more open and more integrated in the formation of the ASEAN Economic Community (AEC) by 2015. In addition to the AEC, ASEAN economic integration is extended with some of their trading partners in a free trade area, namely Japan, Korea, India, Australia, China and New Zealand, through the establishment of RCEP. RCEP's formation, which consists of 16 countries covering nearly $45 \%$ of the world's population, contributes one-third of total world GDP. RCEP negotiations started in 2013 and were expected to be completed at the end of 2015 which aimed to improve and deepen economic arrangements with trading partners in the FTA. RCEP will lead to greater economic integration, support economic development and strengthen economic cooperation. RCEP will cover goods trading; trade in services, investment, economic cooperation and technology, intellectual property, and several other items.

Because of the wealth of human capital which is relatively cheap, Asian countries tend to have advantages in products that are labor-intensive. When referring to the classical theory of Heckscher-Ohlin trade, Asian countries will become exporters of products that are laborintensive. International trading will encourage them to further specialize in these products. Therefore, as a developing country, the capital/labor ratio in Asian countries is relatively lower than in developed countries, so that capital intensity in their industry is also low.

Empirical data in the ASEAN countries + 4 shows that the capital intensity of Japan, Korea, Singapore and Brunei is relatively much higher than in other countries. Those four countries are well known for their industrial structures which tend to be capital-intensive. Cambodia is a country with low capital intensity compared to ASEAN+4 others, while Singapore is the country 
with the highest capital intensity. Almost all countries have been experiencing an increase in capital intensity during the period 2005-17: China and Indonesia experienced the most growth in capital intensity. China's average growth was $25.70 \%$, while Indonesia reached $22.02 \%$. Negative growth experienced in Korea was about $-2.88 \%$, while Japan only grew by an average of $0.92 \%$ in this period. Changes in capital intensity indirectly mean changing the comparative advantage of those countries, from products which are labor-intensive to products that are capital-intensive. On the other hand, the current account of ASEAN Countries +4 showed a declining trend from the period in 2005.

\section{Chart 1. Current Account-GDP ratio ASEAN+4}

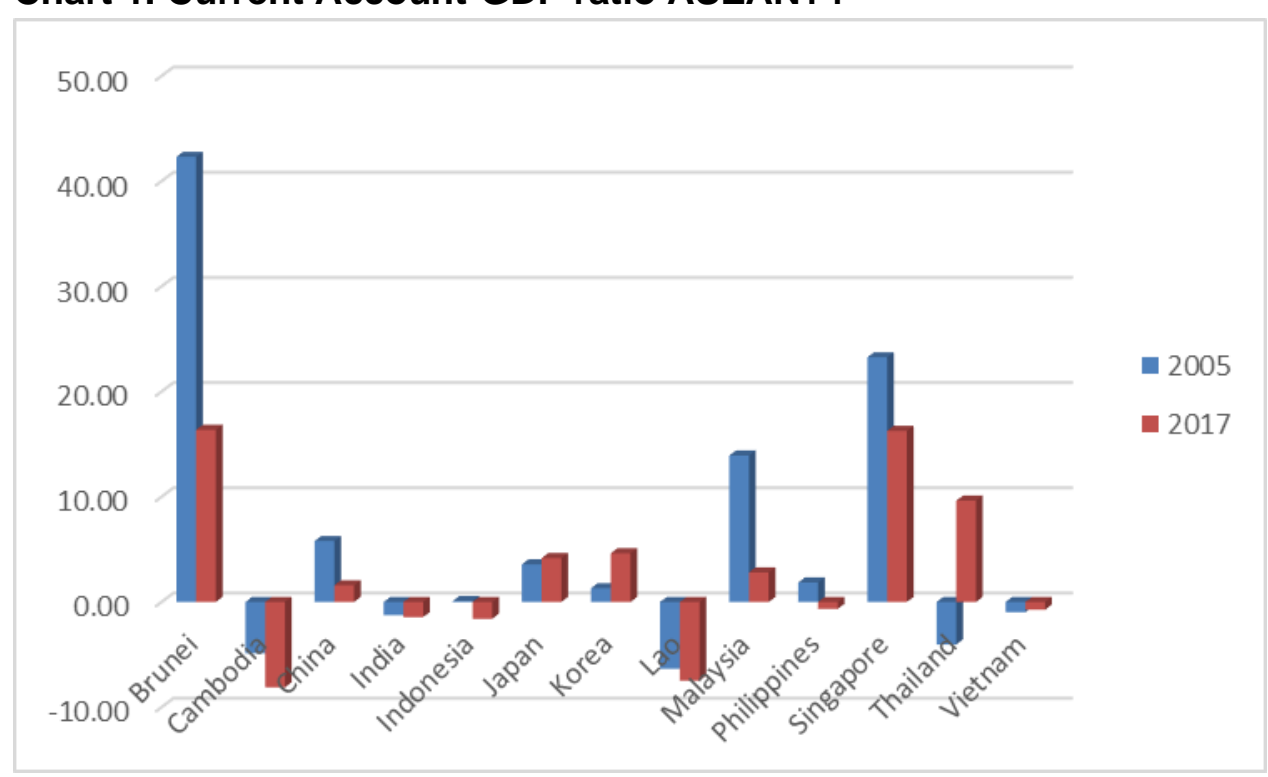

Source: World Bank

An estimation using panel data of countries in ASEAN+4 in the period 2005-17 is shown in Table 1. The main hypothesis proposed is that countries that become increasingly concentrated in industries that are capital-intensive will experience current account deficits over time. It shows that the flow of international capital will go into those countries that have an industrial structure that tends to change due to changes in comparative advantage towards capital-intensive products, due to free trade. As predicted in the new theory, regression with OLS and fixed-effect method shows robust results. The coefficient of negative significant capital intensity affects the current account deficit over time. This means that the greater capital intensity, caused by changes in the structure of the country's comparative advantage towards the industrial structure, is capital-intensive and will bring a bigger current account deficit. Capital intensity in the export of a country and its industrial structure will affect their demand for financial capital, and capital inflows into a country may have an impact on the degree of specialization in industries that are capital-intensive. This result is consistent with studies by Jin (2012) and Setyari et al. (2016) which also show the negative effect of capital intensity on a current account balance. This is related to the industrial structure that affects investment and savings in an economy. The greater the intensity of capital, the more the industrial structure will tend to be capital-intensive. Therefore, the need for investment will be higher than existing savings, so the economy requires greater capital inflows from abroad and this is reflected in a higher current account deficit.

There is also a recognized relationship between the level of income, proxied by per capita income, and the current account deficit. According to the "stages of development" hypothesis, deficits in poor countries are high as their economies start to grow and import more physical 
capital. Later when the economy reaches an advanced status, the current account deficit will decline (Devadas \& Loayza, 2018). Moreover, if developing countries can expect faster income growth as they catch up with industrialized countries, this provides an incentive for them to borrow more from abroad which will lead to current account deficits (Gruber \& Kamin, 2005).

Table 1. Capital Intensity and Current Account Estimation in ASEAN+4

\begin{tabular}{|c|c|c|c|c|c|c|}
\hline \multirow[t]{2}{*}{ Variable } & \multicolumn{2}{|l|}{ OLS } & \multicolumn{2}{|c|}{ Country Fixed Effect } & \multicolumn{2}{|c|}{$\begin{array}{c}\text { Country + Time Fixed } \\
\text { Effect }\end{array}$} \\
\hline & Coefficient & t stat & coefficient & t stat & coefficient & $t$ stat \\
\hline Capital intensity & $\begin{array}{l}-0.00048^{* * *} \\
(0.000110)\end{array}$ & -4.381 & $\begin{array}{l}-0.000613^{* *} \\
(0.000147)\end{array}$ & $\begin{array}{r}- \\
4.164\end{array}$ & $\begin{array}{r}-0.000447^{* \star \star} \\
(0.000129)\end{array}$ & $\begin{array}{r}- \\
3.449\end{array}$ \\
\hline $\begin{array}{l}\text { Financial } \\
\text { development }\end{array}$ & $\begin{array}{l}-0.09907^{* * *} \\
(0.009421)\end{array}$ & 10.516 & $\begin{array}{l}-0.019167 \\
(0.038665)\end{array}$ & 0.495 & $\begin{array}{r}0.016069 \\
(0.036082)\end{array}$ & 0.445 \\
\hline Openness & $\begin{array}{l}0.013194^{\star *} \\
(0.004670)\end{array}$ & 2.825 & $\begin{array}{l}0.034255^{\star \star} \\
(0.015955)\end{array}$ & 2.146 & $\begin{array}{r}0.022473 \\
(0.017198)\end{array}$ & 1.306 \\
\hline GDP & $\begin{array}{r}0.073755 \\
(0.164644)\end{array}$ & 0.447 & $\begin{array}{r}0.129532 \\
(0.126012)\end{array}$ & 1.027 & $\begin{array}{r}0.279972^{*} \\
(0.151789)\end{array}$ & 1.844 \\
\hline $\begin{array}{l}\text { Real Interest } \\
\text { Rate }\end{array}$ & $\begin{array}{r}-0.306639^{* * *} \\
(0.117691)\end{array}$ & -2.605 & $\begin{array}{l}-0.159839 \\
(0.109854\end{array}$ & $\begin{array}{r}- \\
1.455\end{array}$ & $\begin{array}{l}-0.161970 \\
(0.101236)\end{array}$ & 1.599 \\
\hline $\begin{array}{l}\text { Per capita } \\
\text { Income }\end{array}$ & $\begin{array}{l}27.46850^{\star * *} \\
(2.608640)\end{array}$ & 10.529 & $\begin{array}{l}10.51381^{* *} \\
(5.495762)\end{array}$ & 1.913 & $\begin{array}{l}25.44623^{\star * *} \\
(7.845098)\end{array}$ & 3.243 \\
\hline $\begin{array}{l}\text { Ratio of working } \\
\text { age }\end{array}$ & $\begin{array}{r}0.094135 \\
(0.144520)\end{array}$ & 0.651 & $\begin{array}{r}-1.036886^{* * *} \\
(0.208896)\end{array}$ & 4.963 & $\begin{array}{r}-1.168913^{* * *} \\
(0.212487)\end{array}$ & -5.50 \\
\hline $\begin{array}{l}\text { Obs } \\
R^{2}\end{array}$ & $\begin{array}{c}169 \\
0.732396\end{array}$ & & $\begin{array}{c}169 \\
0.889795\end{array}$ & & $\begin{array}{c}169 \\
0.904431\end{array}$ & \\
\hline
\end{tabular}

Note: standard errors in parentheses. The * means sig. at $\alpha=10 \%,{ }^{* *}$ sig. at $\alpha=5 \%$, and ${ }^{* \star *}$ sig. at $\alpha=1 \%$

One of the important determinants of domestic savings is the demographic profile of the population. The results of the analysis indicate that the ratio of the working-age population is negatively correlated with the current account. In the perspective of the determinants of the current account, the demographic profile plays an important role if the profile is different between countries, so it can affect savings. In addition, demographic factors play an important role in the condition of frequency variation of the low current account (Chinn and Prasad, 2000). The lifecycle theory of consumption and saving predicts that young households borrow, middle-age households save for retirement, and households in retirement dis-save. Therefore, relatively young and relatively old countries are both more likely to run current account deficits (Gruber \& Kamin, 2005). 
Other variables that affect the current account, through either savings or investment, are the growth of output. The results of the analysis show no strong effect of GDP growth on current account balance. GDP growth is often associated with increased productivity which is expected to encourage increased investment, and triggers international capital flows to become larger. However, the stronger results of the analysis showed that GDP growth is positively correlated with the current account, which means that countries experiencing high GDP growth tend to be capital outflow, so they become the provider of capital to other countries. In addition, as predicted by the new theory, the increase in productivity will provide a positive shock to the domestic savings of a country which is then allocated both inside and outside the country. Excess savings then encourage capital outflows. Basically, higher average output growth or productivity may either reduce or increase a current account deficit (Devadas \& Loayza, 2018). This depends on whether they signal a temporary or permanent increase in income. If temporary, savings would rise and the deficit declines, especially in the short term. But if the income increase is permanent, consumption and investment would rise and the deficit increase. Empirical results suggest that, on balance, deficits tend to decline with higher average output growth or productivity.

The regression result in the development of financial variables which give inconclusive results with the theory, ${ }^{4}$ which is the existence of a positive relationship between financial sector developments with a current account. The net effect of financial depth is conceptually unclear (Devadas \& Loayza, 2018). It could lead to higher financial savings, but it could also significantly boost consumption and investment through looser borrowing constraints (Bandiera et al., 2000; Chinn and Prasad, 2003). Empirical results, especially those based on credit expansion or excesses, suggest a positive link to larger deficits (see, for example, IMF 2018 and Phillips et al., 2013). Predictions of the theory proposed by Antràs and Caballero (2009) stated that the relationship between trade and international capital flows is complementary because of the difference of the real rate of return of capital. The real rate of return of capital in countries with less developed financial development will be higher than in countries with more developed financial development; thus international capital flows are attracted into the countries which have less developed financial development.

The openness variable is proxied by the ratio of international trade to GDP, showed positively and significantly affects the current account. The degree of economic openness is often associated with trade liberalization. Countries are increasingly open to trade are considered more attractive to foreign investment, allowing them to receive investment to finance the current account deficit with capital from outside. More open economies also tend to have a better ability to manage foreign debt through export earnings. The significant economic openness variable also indicates a complementary relationship between trade liberalization with international capital flows.

One important consequence which may arise from the interaction of trade in goods and international capital flows is not achieving equilibrium factor prices, and of course the price of goods as predicted in the price equalization factors. Because capital tends to go to rich countries, the convergent capital between countries will not be achieved. The difference between the price of the goods in rich countries, both rich in capital and labor, would occur as a consequence of differences in the marginal rate of return. Therefore, the convergence of prices, measured from variant consumer price index (CPI), will not be achieved. Chart 2, where

\footnotetext{
${ }^{4}$ Financial development was proxied by domestic credit ratio to the private sector. A different indicator was used by Chinn and Prasad (2000), which is M2 ratio over GDP, while Jin (2012) used stock market capitalization. However, all results are robust.
} 
the deviation standard of the CPI increases, indicates a widening of the price difference among countries. ${ }^{5}$

\section{Chart 2. Standard Deviation of Consumer Price Index in ASEAN+4}

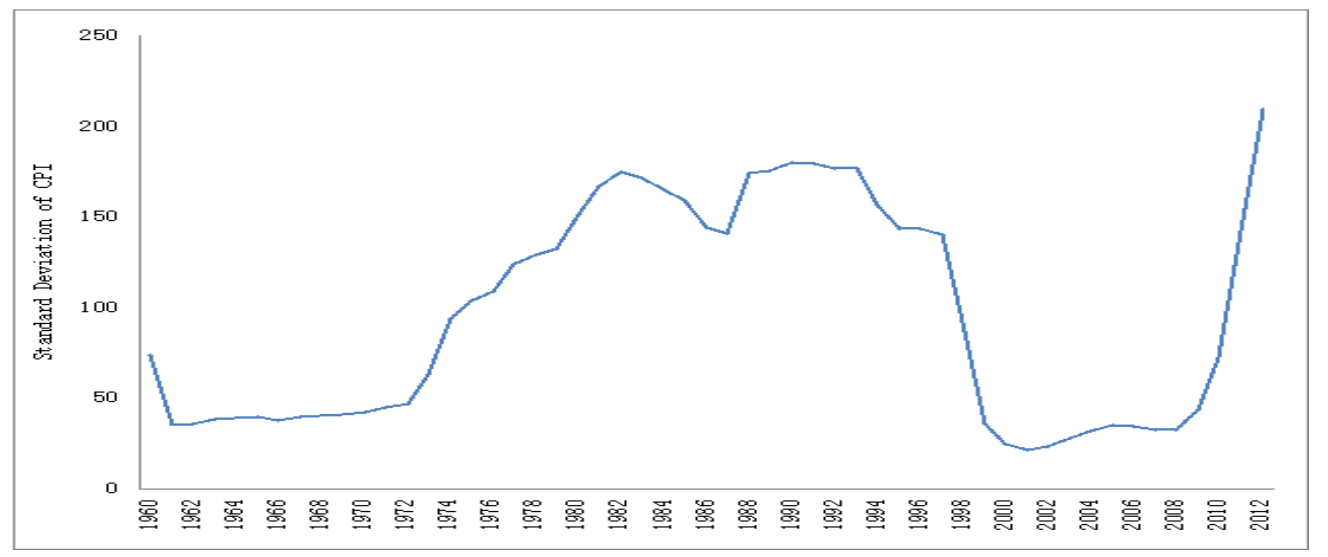

\section{Conclusion}

The discussion about globalization cannot be separated with goods trading and international capital flows. Both topics are often discussed separately and are not seen as an inherent unity as a consequence of the classical thesis of Heckscher-Ohlin-Mundell, who suggested a substitution relationship between them. That is, if the trading in goods has been opened freely with eliminating all forms of obstacles, then there is no incentive for capital to flow between countries.

However, empirical data show a different phenomenon. The development of the trade theory is able to demonstrate that the relationship between trade liberalization of international capital flows is complementary. This paper provides empirical evidence by taking examples of countries in the ASEAN+4 regions, namely the ASEAN countries with their partners in the FTA. Through changes in the industrial structure of comparative advantage, it can be concluded that the countries moving towards capital-intensive industries will be where the current account deficit is getting bigger all the time. Therefore, capital will move towards countries that have a comparative advantage in the industry with products that are capital-intensive.

This study result shows a different way to analyze current account balance. Deficit in current account is not only caused by exports and imports, but also about international capital flows. This empirical result shows several significant variables that effect the current accounts of ASEAN+4 countries. Capital intensity, development stages, and the demographics variable have a strong effect on current account movement, while financial development and economic openness have a relatively weak effect. This research is important to see the linkage between trade liberalization with international capital flows which then determines the allocation of capital globally.

${ }^{5}$ Consumer price index contains tradable and non-tradable goods which can affect the result. Engel and Rogers (1999) use disaggregated data on consumer price to determine of similar goods' price variability across US cities. They find that variability is greater for trade goods. 


\section{References}

Abrego, Lisandro. 1999. Trade Liberalization and Foreign Direct Investment: An Applied General Equilibrium Model for Costa Rica. CSGR Working Paper No. 26/99, April 1999. https://doi.org/10.2139/ssrn.165793

Antras, P. and R.J. Caballero. 2009. Trade and Capital Flows: A Financial Frictions Perspective. Journal of Political Economy, Vol. 117(4): 701-744. https://doi.org/10.1086/605583

Aldaba, Rafaelita M and Josef T. Yap. 2009. Investment and Capital Flows: Implications of the ASEAN Economic Community. Discussion Paper Series No. 2009 - 01. Philippine Institute for Development Studies

Bandiera, O.G., G. Caprio, P. Honohan and F. Schiantavelli. 2000. Does Financial Reform Raise or Reduce Savings? Review of Economics and Statistics 82 (2): 239-263. https://doi.org/10.1162/003465300558768

Chinn, M. D., and E. S. Prasad. 2003. Medium-Term Determinants of Current Accounts in Industrial and Developing Countries: An Empirical Exploration. Journal of International Economics 59 (1, January): 47-76. https://doi.org/10.1016/S0022-1996(02)00089-2

Devadas, Sharmila and Loayza, Norman. 2018. When Is a Current Account Deficit Bad? Research \& Policy Briefs No. 17, October 2018. the World Bank Malaysia Hub

Engel, C. and John H. Rogers. 1999. "Violating the Law of One Price: Should We Make A Federal Case Out of It?" NBER Working Paper No. 7242. https://doi.org/10.3386/w7242

Feenstra, Robert C., Robert Inklaar and Marcel P. Timmer. 2013. "The Next Generation of the Penn World Table" available for download at www.ggdc.net/pwt. https://doi.org/10.3386/w19255

Goldberg, Linda S. and Michael W. Klein, 1999. International Trade and Factor Mobility: An Empirical Investigation. NBER Working Papers No. 7196. https://doi.org/10.3386/w7196

Gruber, Joseph W. and Steven B. Kamin. 2005. Explaining the Global Pattern of Current Account Imbalances. International Finance Discussion Papers Number 846. Board of Governors of the Federal Reserve System. https://doi.org/10.17016/IFDP.2005.846

Hausmann, Ricardo, Jason Hwang, and Dani Rodrik. 2005. What You Export Matters? NBER Working Paper w/11905. https://doi.org/10.3386/w11905

Jin, Keyu. 2012. Industrial Structure and Capital Flows. The American Economic Review, No. 102(5): 2111-2146. https://doi.org/10.1257/aer.102.5.2111

Ju, Jiandong and Shang-Jin Wei. 2006. A Solution to Two Paradoxes of International Capital Flows. IMF Working Paper WP/06/178, July 2006. https://doi.org/10.5089/9781451864380.001

Leamer, Edward E. 1995. The Heckscher - Ohlin Model in Theory and Practice. Princeton Studies in International Finance, No. 77, February 1995

Mundell, Robert A. 1957. International Trade and Factor Mobility. The American Economic Review, Vol. 47(3): 321-335. June 1957

Markusen, J. 1983. Factor Movements and Commodity Trade as Complements. Journal of International Economics (13): 341-56. https://doi.org/10.1016/0022-1996(83)90009-0 
Park, Donghyun, Innwon Park, and Gemma Esther B. Estrada.2008. Prospects of an ASEAN-People's Republic of China Free Trade Area: A Qualitative and Quantitative Analysis. ADB Economics Working Paper Series No. 130. October 2008

Romalis, John. 2004. Factor Proportions and the Structure of Commodity Trade. The American Economic Review, Vol. 94(1):67-97. https://doi.org/10.1257/000282804322970715

Schiff, Maurice. 2006. Substitution in Markusen's Classic Trade and Factor Movement Complementarity Models. World Bank Policy Research Working Paper 3974, August 2006. https://doi.org/10.1596/18139450-3974

Springer, Katrin. 2000. Do We Have to Consider International Capital Mobility in Trade Models? Kieler Arbeitspapiere, No. 964

Shirotori, Miho, Bolormaa Tumurchudur, and Olivier Cadot. 2010. Revealed Factor Intensity Indices at the Production Level. Policy Issues in International Trade and Commodities Study Series No. 44. United Nation

Shiino, K. 2012. Overview of Free Trade Agreement in Asia.In Cause and Consequence of Firms' FTA Ulitization in Asia, edited by Kazunobu Hayakawa. BRC Research Report No. 9. Bangkok Research Center. IDE-JETRO, Bangkok, Thailand

Setyari, Ni Putu Wiwin, Purbadharmaja, Ida Bagus Putu, and Karmini, Ni Luh. 2016. Industrial structure, demographic pattern, and Indonesian current account. Journal of Economics, Business, and Accountancy Ventura Vol. 19(3): 315 - 324. https://doi.org/10.14414/jebav.v19i3.619

Widodo, Tri. 2008. Factor Endowments and Comparative Advantages of East Asia. Economics and Finance in Indonesia, Vol. 56 (2): 215-242. https://doi.org/10.7454/efi.v56i2.23

Wooldridge, Jeffry M. 2005. Introductory Econometrics: A Modern Approach. Fourth Edition. South Western

Wong, K.-Y. (1986). Are International Trade and Factor Mobility Substitutes? Journal of International Economics 21: 341-356. https://doi.org/10.1016/0022-1996(86)90003-6

Yue, Chia Siow. 2004. ASEAN-China Free Trade Area. AEP Conference Hong Kong. 12-13 April 2004

Zhang, Guoxiong. 2012. Trade Liberalization and Capital Flows: a Perspective of Comparative Advantage and Heterogenous Firms. Job Market Paper October 2012. Department of Economics University of California 